\title{
Temporal and spatial variability in concentrations of phosphorus species under thermal pollution conditions of a dam reservoir - the Rybnik Reservoir case study
}

\author{
Maciej Kostecki, Malwina Tytła*, Joanna Kernert, Katarzyna Stahl \\ Institute of Environmental Engineering, Polish Academy of Sciences in Zabrze, Poland \\ *Corresponding author's e-mail: malwina.tytla@ipis.zabrze.pl
}

Keywords: phosphorus speciation, bottom sediments, dam - reservoirs, thermal pollution

\begin{abstract}
The research objective was to study temporal and spatial relations between specific phosphorus species as well as to examine total phosphorus content in the bottom sediments of an anthropogenic, hypertrophic limnic ecosystem Rybnik Reservoir, functioning under thermal pollution conditions. The chemical extraction procedure for the speciation of bioavailable phosphorus forms was used. It was found that available algae phosphorus was the most dominant phosphorus species in both sediment layers (83\%), while the lower share was readily desorbed phosphorus form $(0.1 \%)$. The phosphorus species concentrations depended on the organic matter concentration. The differences between phosphorus species contents in the upper $(5 \mathrm{~cm})$ and lower $(15-20 \mathrm{~cm})$ sediment core layers were low. The biologically active sediment layer extended from the sediment surface to at least $20 \mathrm{~cm}$ depth of the sediment core. Distributions of the concentrations within the year and at specific sampling points resulted from the variability observed for particular points and transformation intensity. Furthermore in the following study, the reaction rate constant for the increase and decrease in the concentrations of the phosphorus species in sediments was given. It was indicated that the speed of the phosphorus species transformations was affected by the environment temperature. In the heated water discharge zone (water temp. $17-35^{\circ} \mathrm{C}$ ) the concentrations of selected speciation phosphorus forms increased more than in the dam zone $\left(5-25^{\circ} \mathrm{C}\right)$. It was also found that the abundance of the bottom sediments with phosphorus species was related to the oblong and transverse asymmetry of reservoir depth.
\end{abstract}

\section{Introduction}

Thermal pollution is one of the anthropopressure forms contributing to intensive primary and secondary production of the limnic ecosystem. The phenomenon is particularly visible in the reservoirs used by power plants to supply the cooling systems (Kostecki 2004, Stawecki et al. 2004, Kostecki 2005a). Phosphorus is an element that decides on the intensity of metabolic processes (Wang and Liang 2015). Its compounds are introduced into a water ecosystem together with the supplying watercourse waters (Kostecki and Kozłowski 2002, Kostecki 2005b), flows from the direct catchment area (Sondergaard 1988, Kowalczewska-Madura et al. 2015), and atmospheric precipitation (Kostecki 2002, Kostecki 2003, Koszelnik 2007, Sapek and Sapek 2011). In the watercourse waters, phosphorous species are mostly present in suspensions (Pettersson 1988, Kostecki 2000). The researchers emphasize the role of the land types in the catchment area on which the amount and quality of the phosphorus species introduced into surface waters depend (Bostrom et al. 1998, Kostecki 2003, Sapek and Sapek 2011).

The formation of insoluble phosphorus forms deposited in the bottom sediments is related to the amount and characteristics of the pollutants introduced into the ecosystem waters (Dunalska et al. 2014, Kowalczewska-Madura et al. 2015). Part of the phosphorus loads passes into the bottom sediments together with the organic matter formed in the primary production process (Williams et al. 1980, Smal et al. 2015). Iron, aluminium, calcium and magnesium compounds play a special role in the processes of binding and precipitation of mineral phosphorus forms from water (Olsen et al. 1954, Frankowski et al. 2002, Gawrońska et al. 2008). Moreover, some nitrogen forms can develop insoluble forms with phosphorus under appropriate thermal, oxygen and $\mathrm{pH}$ conditions - forming a magnesium ammonium phosphate called struvite (Pettersson et al. 1998, Smal et al. 2013). Additionally, mineral suspensions with different chemical compositions (introduced into the reservoir with atmospheric precipitation) may intensify the transformation of the soluble phosphorus forms into the insoluble ones (Koszelnik 2007).

The two-way exchange of phosphorus between water and bottom sediments is one of the main elements of the matter circulation process in a water ecosystem (Siuda 2001, Bartoszek 2007, Wand and Liang 2015). Specific phosphorus species are responsible for the process of binding and releasing phosphorus from bottom sediments into water (depending 
on the conditions in a given reservoir). They also define the phosphorus bioavailability for living organisms. The limnic ecosystem ability to store or release phosphorus results from a number of its characteristics, such as supplying water quality, depth, ability to stratify, thermal and oxygen conditions, and retention time (Gawrońska et al. 2008, Kostecki and Suschka 2013, Dunalska et al. 2014, Kostecki 2014). Those characteristics decide on the influence of the phosphorus loads accumulated in the sediments on the trophic state of a water reservoir. For that reason, phosphorus and its species are thought to be the key element enabling researchers to understand the transformation cycle of this element (Gonsiorczyk et al. 1998, Kowalczewska-Madura et al. 2005). It is necessary for protection and reclamation of limnic ecosystems.

The aim of speciation analysis is to determine (with appropriate extractants) the abundance and possible release of phosphorus from the bottom sediments into water under conditions of a specific water ecosystem (Nurnberg et al. 1987, Aimin et al. 2005). Applying the same research methodology to different ecosystems helps to compare the results and draw conclusions on the role of bottom sediments (pollutant storage) as the threat for the environmental reservoir condition. It should also help to indicate the environmental conditions that either increase or reduce such a risk (Zhou and Zhu 1999, Aydin et al. 2009).

Numerous studies demonstrate that the complexity of environmental conditions in limnic ecosystems affects their diversity in terms of spatial abundance with phosphorus species (Pettersson et al. 1988, Sondergaard 1988). The differences between specific reservoirs (even similar ones) result in the research and comparison of the bottom sediment compositions (Zhou and Zhu 1999, Zhou et al. 2000, Zhou et al. 2001, Smal et al. 2013). The researchers emphasize the role of various aspects (such as the formation genesis, type and amount of the supplied pollutants, and morphometric conditions) in the formation of proportions and correlations between phosphorus species (Sharpley et al. 1991, Smal et al 2015). The research has indicated the significance of such issues as the suspension particle size, differences in the phosphorus contents in the auto- and allochtonic suspensions, and influence of the plant coverage (coniferous and deciduous forests) on the phosphorus leaching from the catchment area soils (Bostrom et al. 1998, Kostecki and Nocoń 2010).

\section{Research area}

Rybnik Reservoir $\left(50^{\circ} 8^{\prime} \mathrm{N}, 18^{\circ} 30^{\prime} \mathrm{E}\right)$ is a dam reservoir (area of $450 \mathrm{ha}$; volume of 21 million $\mathrm{m}^{3}$ ). It is an element of the power plant technology. It functions under the so-called "thermal pollution" conditions. Water is first taken from the reservoir and afterwards it is discharged in the heated form. In summer, the water temperature ranges between $35^{\circ} \mathrm{C}$ (heated water discharge zone) and $27^{\circ} \mathrm{C}$ (dam zone). The reservoir does not freeze in winter and the temperature ranges between $17^{\circ} \mathrm{C}$ (heated water discharge zone) and $5-7^{\circ} \mathrm{C}$ (dam zone). Anthropomixion (mixing of water masses under the influence of water intake and discharge by the power plant) is forced by the technological process which oxygenates the water. Movements of the water masses inside the reservoir basin are related to the morphometric conditions. The reduction in the linear velocity of the water flow is favourable to the sedimentation of the decayed biomass and its deposition in the bottom sediment form.

\section{Research objective and scope}

The research objective was to study temporal and spatial relations between specific phosphorus species as well as to examine total phosphorus content in the bottom sediments of an anthropogenic, hypertrophic limnic ecosystem functioning under thermal pollution conditions. The speciation research results are presented for the bioavailable phosphorus fractions, i.e. water-soluble phosphates (WSP), readily desorbed phosphates (RDP), phosphates bound to iron and aluminium, available for algae (AAP), and phosphates extracted with acidic sodium bicarbonate (EP; the so-called Olsen-P). The above mentioned relations are presented with consideration for the morphometric conditions, characteristic for the oblong and transverse asymmetry of the reservoir basin.

\section{Methodology}

The sediment samples were collected in two transects due to the characteristic oblong and transverse asymmetry of the reservoir depth (vertical distance from the water surface to the bottom of the reservoir).

\section{Transect 1}

Sampling point 1 (T1-S1) was located close to the outlet of the discharge water reservoir for the power plant (depth $=$ approx. $1.5 \mathrm{~m})$. Sampling point 2 (T1-S2) was located in the central part of the reservoir (depth $=3-4 \mathrm{~m})$. Sampling point 3 (T1-S3) was located in the dam zone $($ depth $=7-8 \mathrm{~m})$.

\section{Transect 2}

Sampling point 1 (T2-S1) was located close to the outlet of the discharge water reservoir for the power plant at approx. $250 \mathrm{~m}$ from the side reservoir dike (depth = approx. $3 \mathrm{~m}$ ). Sampling point 2 (T2-S2) was located in the central part of the reservoir (depth $=4-5 \mathrm{~m})$. Sampling point 3 (T2-S3) was located in the dam zone (depth $=8-9 \mathrm{~m})$. The distances between the respective sampling points for both transects were approx. $500 \mathrm{~m}$.

In 2012, samples were collected monthly between May and December ( 7 times) whereas in 2013 between January and December (12 times). The sediments were collected with the Birge-Ekman sampler from the sediment upper layer (UL; $5 \mathrm{~cm}$ thickness) and lower layer (LL; 15-20 cm of the sediment core thickness). Samples were stored at $4^{\circ} \mathrm{C}$ in a refrigerator.

\section{Analysis methodology}

The chemical extraction procedure for the phosphorus forms and bioavailability analysis principles were used in the study (Zhou et al. 2001). It was selected due to its simplicity and detailed description available in the literature. As the studied extract had to be filtered, the quantity of the used sediments was increased proportionally to the reagent's volume, which equaled to $200 \mathrm{ml}$. The following bioavailable phosphorus fractions were investigated:

- AAP - it represents phosphorus bound to metal oxides (mainly iron and aluminium) and organic matter defined as the availability measure for algae. $0.8 \mathrm{~g}$ of wet 
sediment was extracted with $200 \mathrm{ml}$ of 0.1 mole sodium hydroxide $-\mathrm{NaOH}$, for $4 \mathrm{~h}$;

- EP (Olsen-P) - it is treated as indicator describing the abundance of soils (and sediments) with phosphorus, quantitative indicator for available phosphorus, and fraction helping to make conclusions on the critical level for the plant production (not only in the water environment). $10 \mathrm{~g}$ of wet sediment was extracted with $200 \mathrm{ml}$ of 0.5 mole sodium bicarbonate $-\mathrm{NaHCO}_{3}(\mathrm{pH}=8.5)$, for $0.5 \mathrm{~h}$;

- WSP - it is defined as the most bioavailable phosphorus fraction. $1 \mathrm{~g}$ of wet sediment was extracted with $200 \mathrm{ml}$ of distilled water, for $2 \mathrm{~h}$;

- RDP - it defines phosphorus desorbed from the surface of the bottom sediment particles. $8 \mathrm{~g}$ of wet sediment was extracted with $200 \mathrm{ml}$ of 0.01 mole calcium chloride $-\mathrm{CaCl}_{2}$, for $1 \mathrm{~h}$.

Additionally, the organic matter content (OM), $\mathrm{pH}$, and Eh were determined.

\section{Sample pretreatment for phosphorus, OM content, $\mathrm{pH}$, and Eh determination}

$1 \mathrm{~g}$ of wet sediment was mineralized to the white fumes and "clear liquid" with $1 \mathrm{ml}$ of concentrated sulfuric acid $\left(\mathrm{H}_{2} \mathrm{SO}_{4}\right)$ and $8 \mathrm{ml}$ of concentrated nitric acid $\left(\mathrm{HNO}_{3}\right)$. The mineralization product was brought by the $20 \% \mathrm{NaOH}$ and phenolphthalein to the $\mathrm{pH} \approx 8.3$ and afterwards it was supplemented with $50 \mathrm{ml}$ of distilled water.

For phosphorus determination the Varian UV-VIS 50 spectrophotometer was applied at a wavelength of $880 \mathrm{~nm}$ with incorporation of the ascorbic acid $\left(\mathrm{C}_{6} \mathrm{H}_{8} \mathrm{O}_{6}\right)$ as a reducing agent. The obtained results were recalculated and presented as a phosphorus amount contained in $\mathrm{g} / \mathrm{kg}$ of dry matter (DM).

The organic matter content was determined in accordance to PN-C04541:1978. Additionally $\mathrm{pH}$ and Eh were determined using multi-function device CX-401 Elmetron equipped with electrode ERH-111 Hydromet and ERPt-111 Hydromet. All studies were carried out in accordance to the applicable research standards.

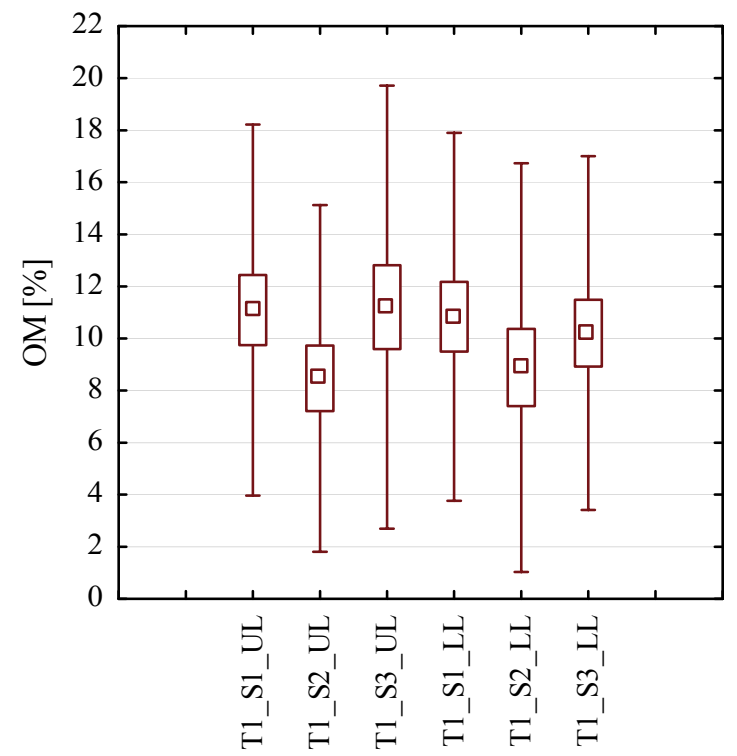

\section{Statistical analysis}

In order to determine the relationship between the studied variables (i.e. Eh, TP and AAS, EP, WSP, RDP - depending on the sampling sites, transects and its depth), the Pearson correlation coefficient $(\mathrm{p}<0.05)$ and Independent T-Test for Two Samples were applied. Data analysis also included the mean and standard deviation (SD). The statistical analyses were performed using Statistica ver. 12.

\section{Results and discussion}

\section{Organic matter content}

The organic matter content in the sediment samples from Transect 1 was approx. twice as low as the content in the samples from Transect 2 (Fig. 2).

At the same time, the range of changes in the organic matter content in the bottom sediments at Transect 1 sampling points was $2-16 \%$. In other words, it was much higher than the range determined for Transect 2 sampling points (12-27\%).

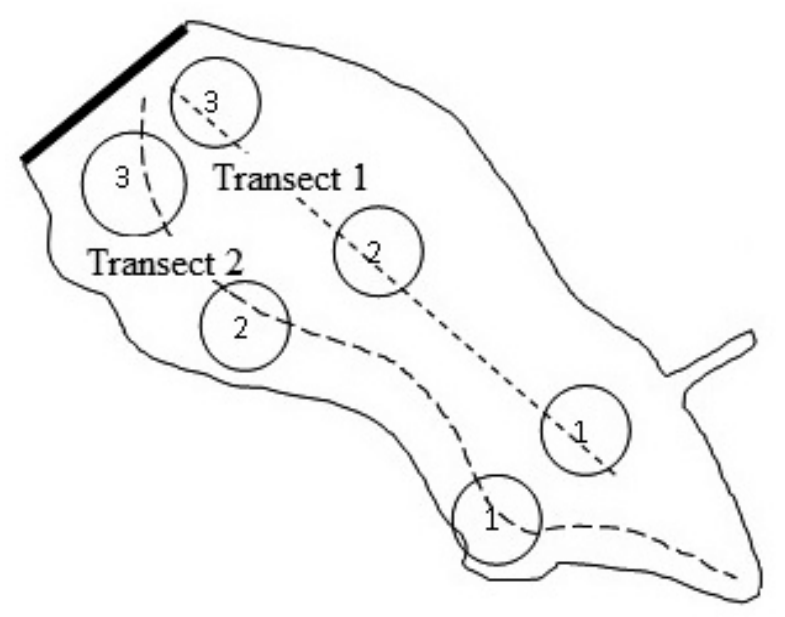

Fig. 1. Location of the bottom sediment sampling points - Rybnik Reservoir

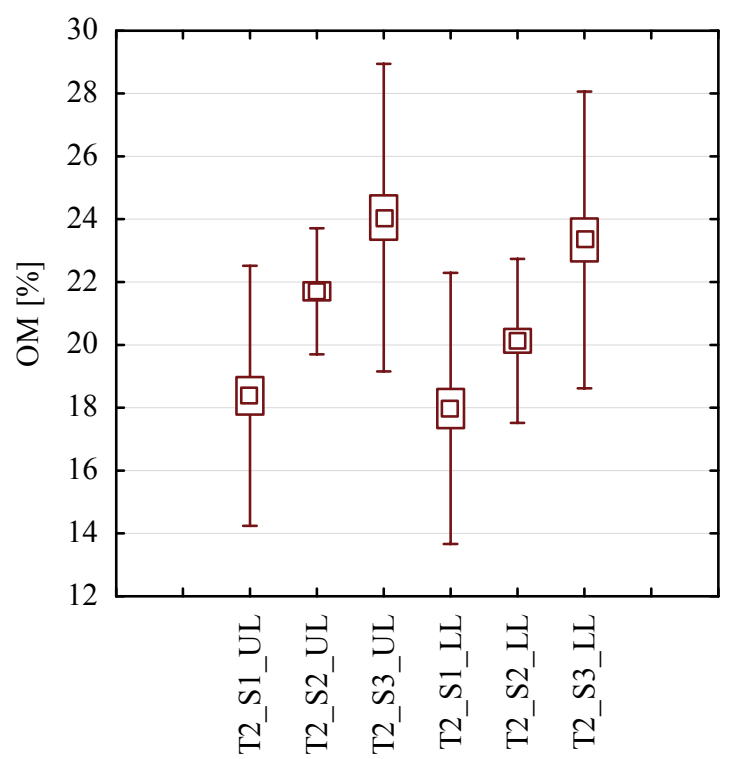

Fig. 2. Organic matter contents in the bottom sediments of Rybnik Reservoir 
The maximum values were observed at the dam zone sampling point in Transect 2, both in the lower and upper sediment layers. The lowest organic matter content was determined for the upper reservoir part in the heated water discharge zone (upper layer: 15-21\%; lower layer: 12-21\%). The values for the central (pelagic) reservoir zone were slightly higher, i.e. 20-23\% (UL) and 19-23\% (LL). The organic matter content was $18-26 \%$ (UL) and $17-27 \%$ (LL) in the bottom sediments sampled at the dam zone. The results of Independent T-Test for Two Samples confirmed that there is a statistically significant difference between the means in two considered groups i.e. Transect 1 and Transect 2 (obtained p value was lower than $0.05)$.

\section{pH}

The differences in $\mathrm{pH}$ for both transects were low. $\mathrm{pH}$ ranged between 7.1 and 7.7 (Transect 1), and 7.1 and 7.8 (Transect 2). What is more, the differences between $\mathrm{pH}$ of the upper and lower layers were also slight (Fig. 3). The results of Independent T-Test for Two Samples confirmed that there is no statistically significant difference between the means in two considered groups i.e. Transect 1 and Transect $2(p>0.05)$. The obtained $p$-value for UL in Transect 1 vs Transect 2 equals $=0.8055$, whereas in the case of LL $p=0.2068$.

\section{Redox potential}

Eh value was between $-107 \mathrm{mV}$ and $-269 \mathrm{mV}$ for Transect 1 and between $-130 \mathrm{mV}$ and $-304.3 \mathrm{mV}$ for Transect 2 (Fig. 4). The results of Independent T-Test for Two Samples confirmed that there is no statistically significant difference between the means in two considered groups $(\mathrm{p}>0.05)$. The obtained p-value for UL in Transect 1 vs Transect 2 equals $=0.5697$, whereas in the case of LL $p=0.7325$. The differences observed for $\mathrm{Eh}$ in the upper and lower sediment layers were small. Slightly lower values (indicating the reduction conditions for sediments) were observed for the lower sediment layer.
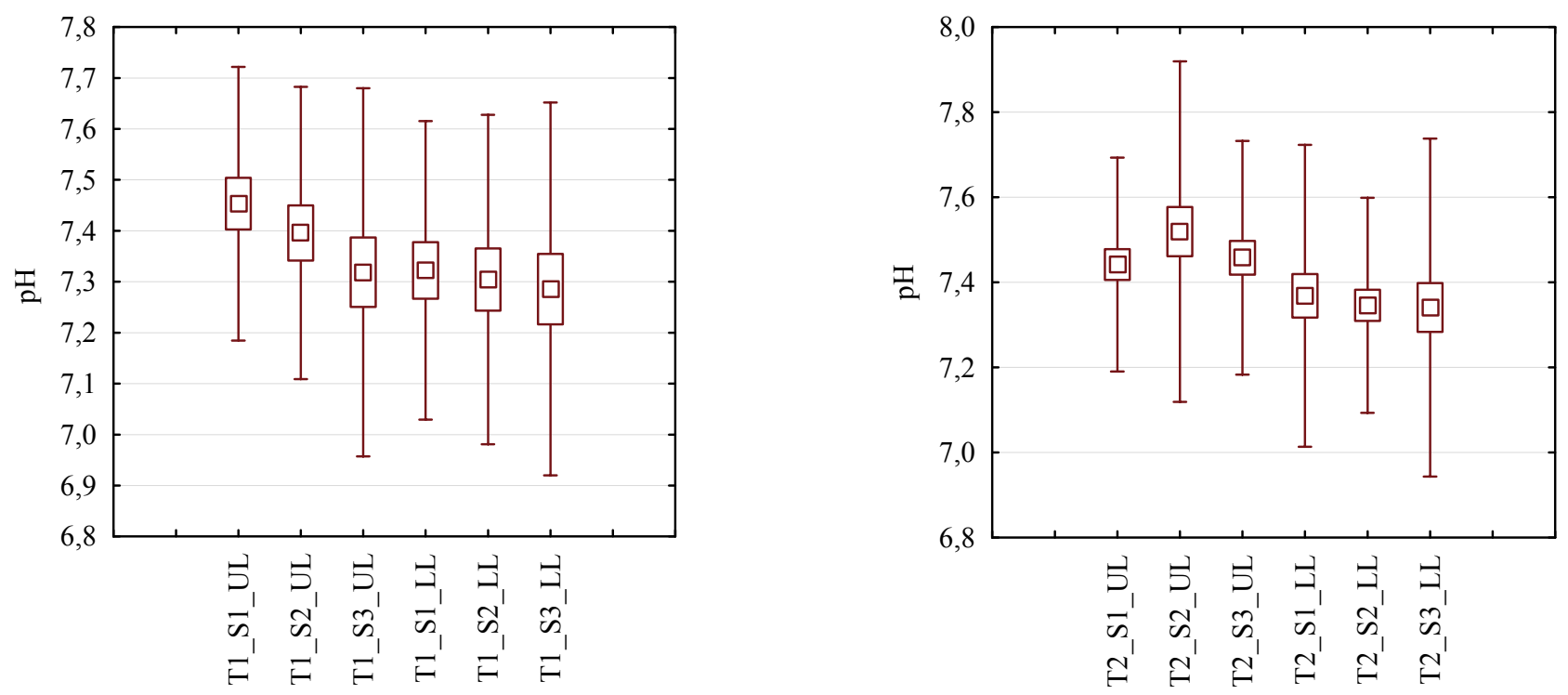

Fig. 3. $\mathrm{pH}$ of the Rybnik Reservoir bottom sediments
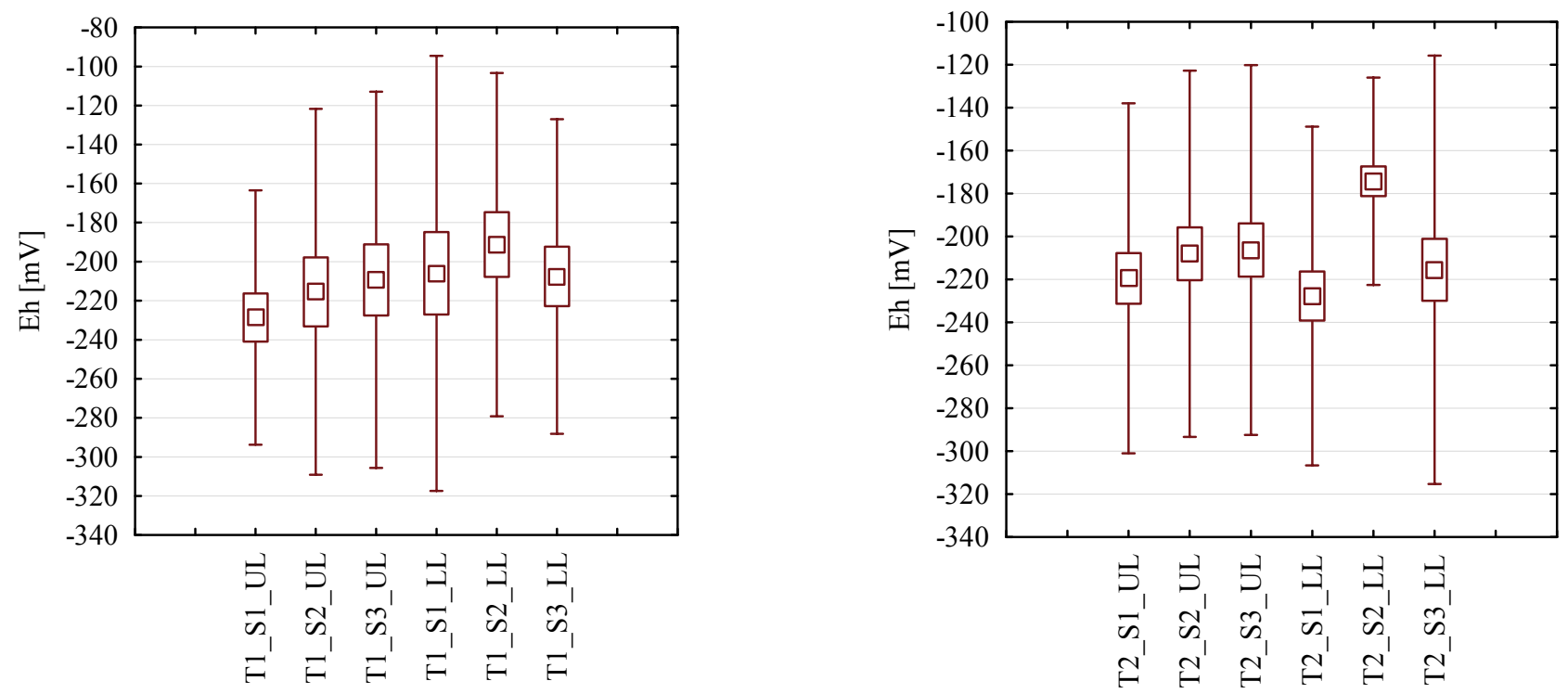

Fig. 4. Eh of the Rybnik Reservoir bottom sediments 


\section{Phosphorus speciation forms}

The research into phosphorus species in the sediments of hypertrophic and thermally polluted Rybnik Reservoir demonstrated that the contents of specific phosphorus species were not stable (Figs. 5, 6, 7). The discovered seasonal variability in the concentrations demonstrated visible increasing and decreasing trends during the year. The finding concerns all the speciation forms and both investigated sediment layers with consideration for large similarity of changes in time and space. The increase in specific speciation form concentrations normally occurred in the first half of the year (January-July), whereas the decrease was observed in the second half of the year (July-December). The range of changes in the concentrations

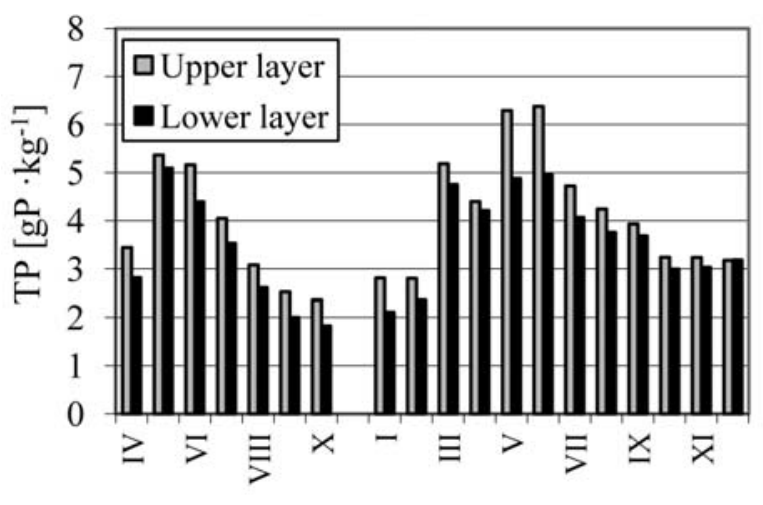

Transect 1

Months

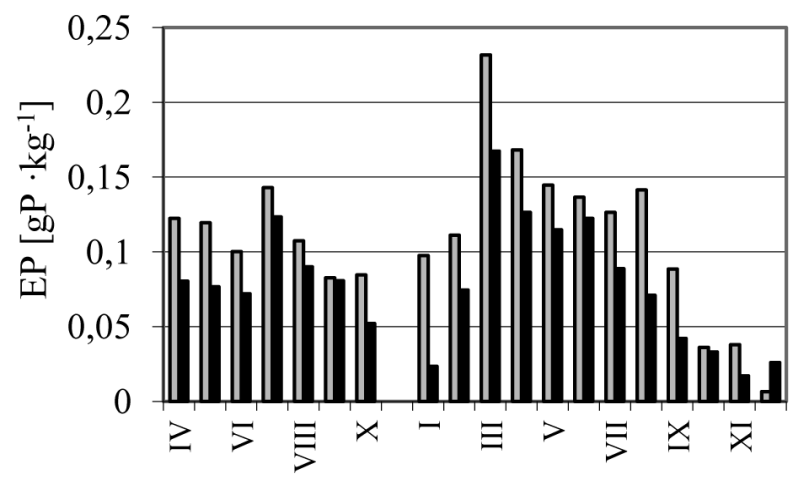

Transect 1

Transect 2

Months of specific phosphorus species was different while the trends in the changes were similar. As simultaneous decrease in one phosphorus species concentration and increase in other species concentrations were not observed, it was impossible to confirm the passing of one species into another. Other researchers also confirmed that finding (Zhou et al. 2000, Kaiserli et al. 2002, Kowalczewska-Madura et al. 2005, Aydin et al. 2009).

The processes occurring in water result in the phosphorus binding and depositing in the bottom sediments (Kowalczewska-Madura et al. 2005, Bartoszek 2007, Dunalska et al. 2014). Under oxygen conditions, even persistent pollutants may undergo decomposition (Kostecki and Mazierski 2008). Under anoxic conditions, transformations of phosphorus compounds

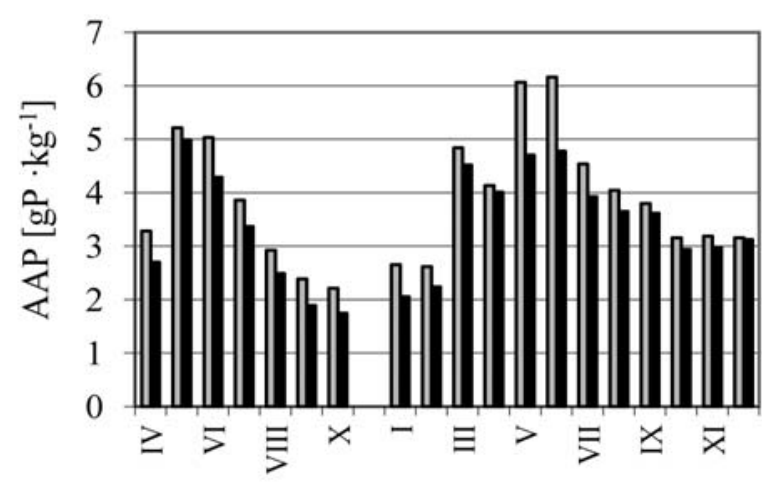

Transect 1 Months

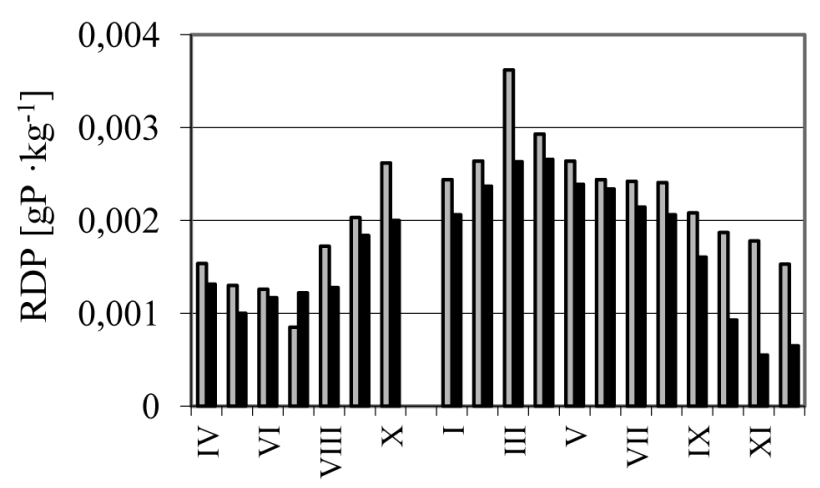

Transect 1

Months

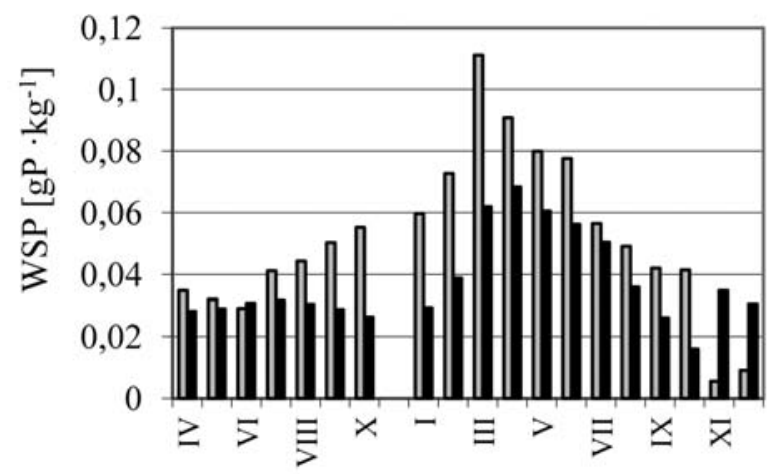

Transect 1

Transect 2

Months

Fig. 5. Concentrations of phosphorus species in the Rybnik Reservoir bottom sediments - heated water discharge zone 
result in the phosphorus passing from bottom sediments into water.

The speed of the increase in the particular phosphorus form concentrations in the upper and lower sediment layers was higher than the speed of the concentration decrease, which finally reflected the phosphorus accumulation process in the bottom sediments (Table 1). For TP, the increase speed was higher than the decrease speed by $26 \%$ and $45 \%$ in the upper and lower sediment layers, respectively. For AAP, the values were by $37 \%$ and $43 \%$ higher in the upper and bottom sediment layers, respectively. For EP (Olsen-P), the values were 29\% and $44 \%$, respectively, whereas for RDP they were $20 \%$ and $1 \%$, respectively. For WSP, the decrease in this phosphorus

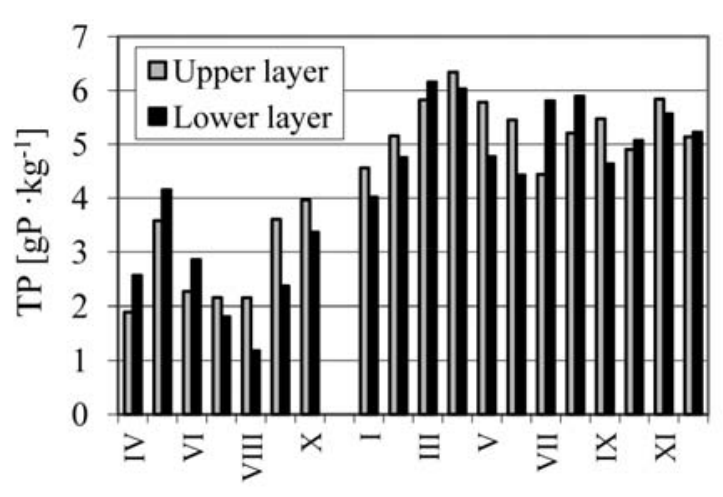

Transect 1

Transect 2

Months

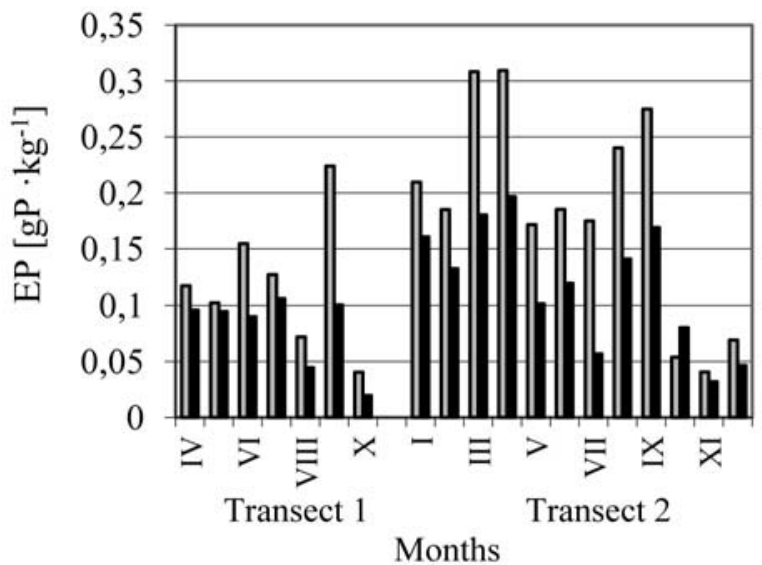

Months species was by approx. $45 \%$ faster than its increase in the upper sediment layer.

The speed of the phosphorus transformations in the bottom sediments was affected by the reaction environment temperature. In the heated water discharge, TP and AAP concentrations increased faster, i.e. by $33 \%$ higher than in the dam zone. The decrease in the TP and AAP concentrations was by approx. $32-39 \%$ higher. At the same time, the increase and decrease in the EP (Olsen-P) concentration was by $87 \%$ faster in the colder part of the reservoir (by $175 \%$ ) than in the warmer upper reservoir part (Fig. 8).

For phosphorus, the number of forms able to pass from bottom sediments into water (which are later included in the food
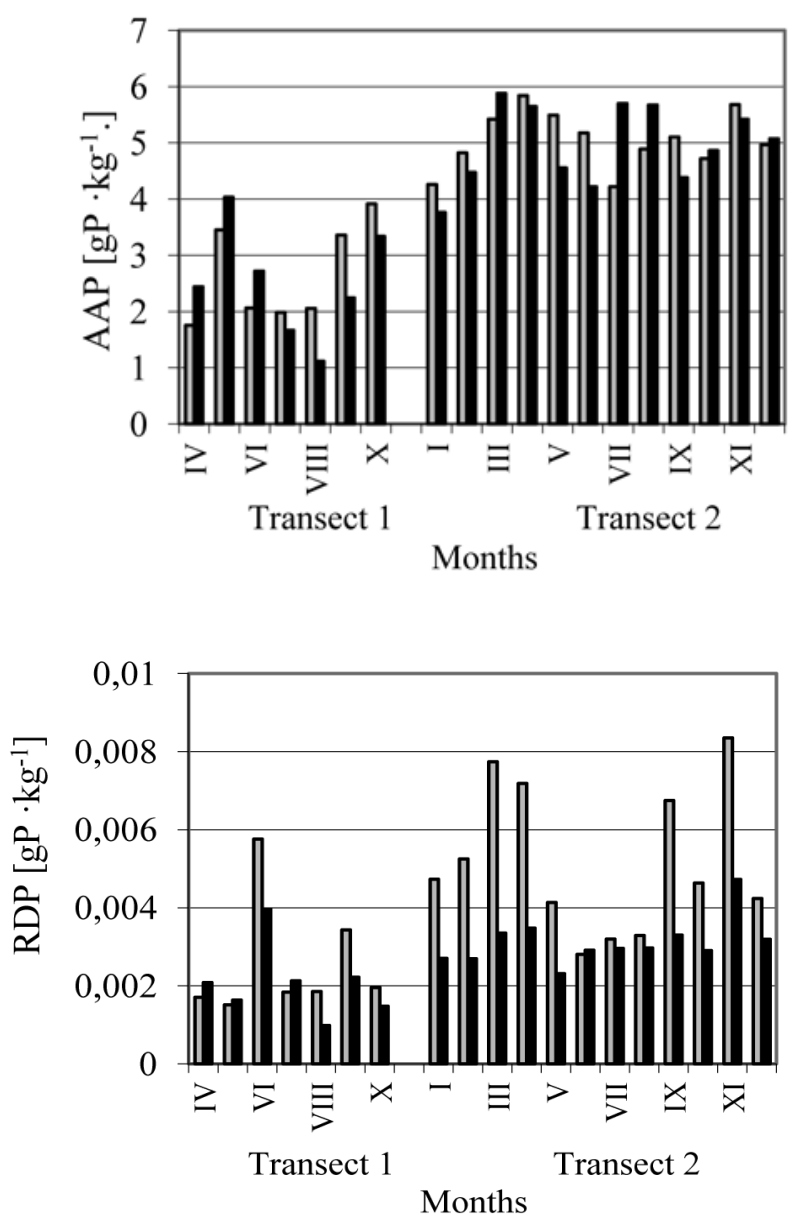

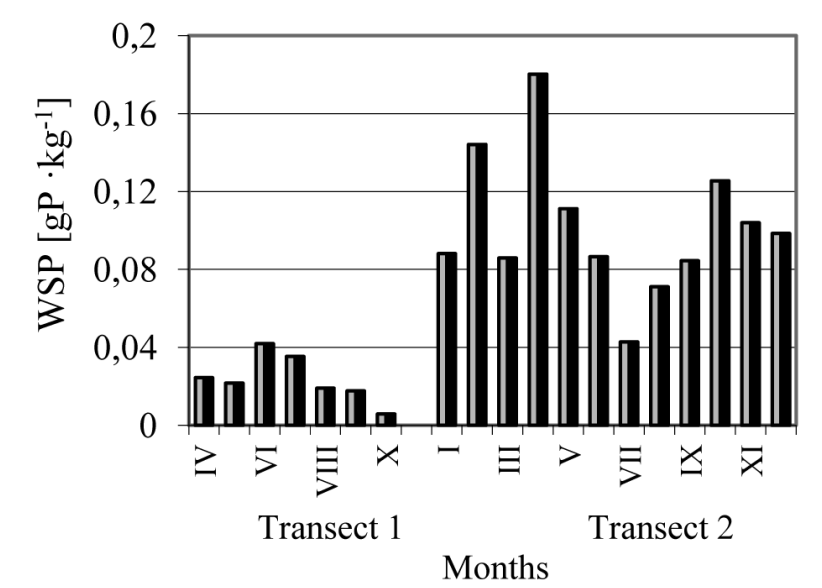

Fig. 6. Concentrations of phosphorus species in the Rybnik Reservoir bottom sediments - pelagic zone 
chain) decides on the real threat of eutrophication for a limnic ecosystem (Nurnyberg et al. 1987, Kowalczewska-Madura et al. 2005, Kostecki 2014). The research results indicate that bottom sediments accumulate large phosphorus loads under conditions of a thermally polluted hypertrophic ecosystem. The estimated phosphorus loads in the bottom sediments of three dam reservoirs are presented below (Table 2).

For hypertrophic Rybnik Reservoir, the dominant AAP form percentage (in comparison to the sum of specific forms) was $97 \%$ and was higher than the percentage determined for b-mesotrophic Pławniowice Reservoir (83\%) (Kostecki 2014).

The anthropomixion phenomenon contributed to such accumulation in the investigated reservoir. It was caused by

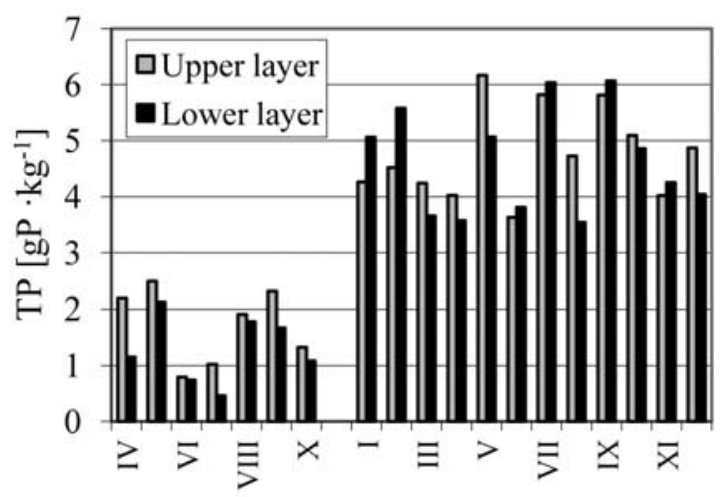

Transect 1

Transect 2

Months

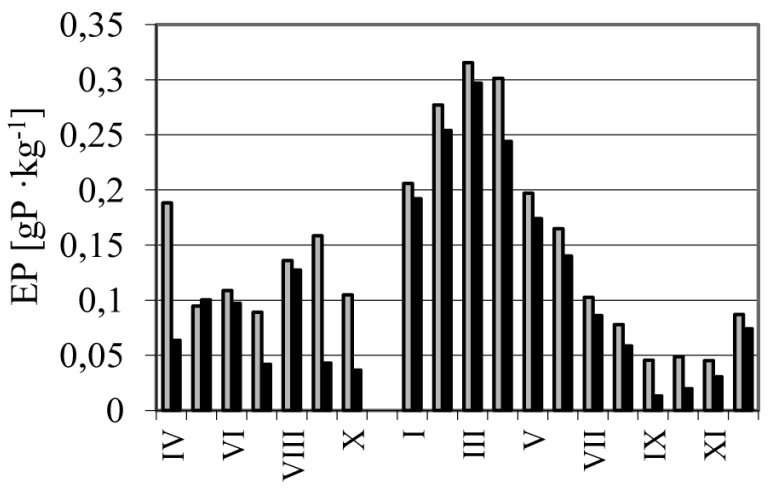

Transect 1

Months continuous mixing of the water masses due to the water intake and discharge for the technological needs of the power plant (Kostecki 2004, Kostecki 2005a). Consequently, water was constantly oxygenated, which resulted in the lower percentage of Olsen-P, WSP and RDP (in relation to TP).

\section{Eh vs phosphorus speciation forms}

Pearson's correlation coefficients between the phosphorus species concentrations and redox potential in the bottom sediments indicate that RDP, EP and WSP were the most sensitive to the redox potential changes (especially in the case of heated water discharge zone). Whereas, there were no statistically significant dependencies in reference to TP and AAP vs Eh (Table 3).

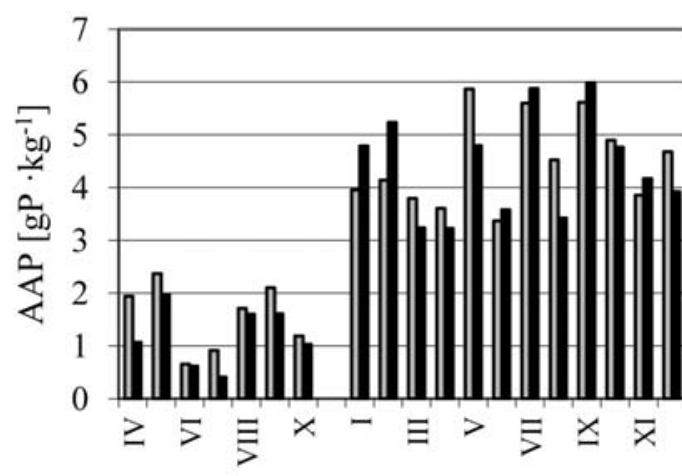

Transect 1 Transect 2

Months

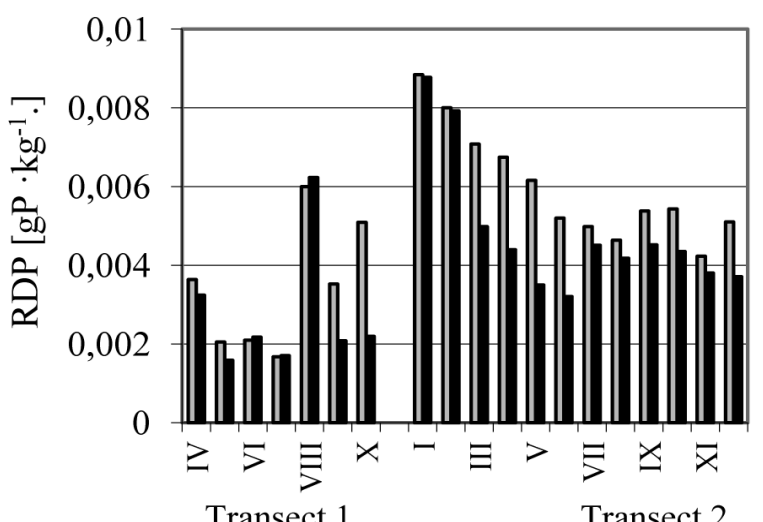

Months

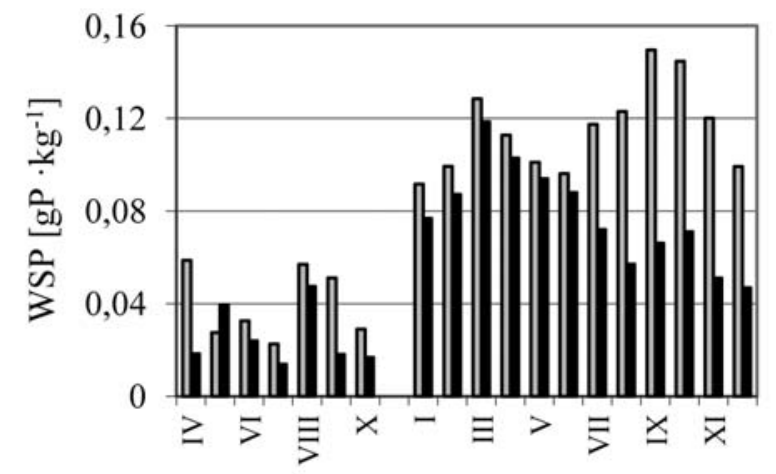

Transect 1

Months

Fig. 7. Concentrations of phosphorus species in the Rybnik Reservoir bottom sediments - dam zone 
Table 1. The reaction rate constant $\left[\mathrm{gP} \cdot \mathrm{d}^{-1}\right]$ of the increase and decrease in the phosphorus species concentrations in the Rybnik Reservoir bottom sediments - mean values

\begin{tabular}{|c|c|c|}
\hline Parameter & $\begin{array}{l}\text { Increased concentration } \\
{\left[\mathrm{gP} \cdot \mathrm{d}^{-1}\right]}\end{array}$ & 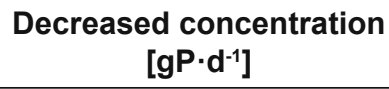 \\
\hline \multicolumn{3}{|c|}{ UPPER LAYER } \\
\hline TP & $0.02885 \pm 0.0141$ & $0.02121 \pm 0.0001$ \\
\hline AAP & $0.02070 \pm 0.0089$ & $0.01303 \pm 0.0079$ \\
\hline EP (Olsen-P) & $0.00197 \pm 0.0005$ & $0.00140 \pm 0.0008$ \\
\hline WSP & $0.00078 \pm 0.0002$ & $0.00113 \pm 0.0006$ \\
\hline RDP & $0.00004 \pm 0.0001$ & $0.00003 \pm 0.0001$ \\
\hline \multicolumn{3}{|c|}{ LOWER LAYER } \\
\hline TP & $0.02915 \pm 0.0083$ & $0.01610 \pm 0.0040$ \\
\hline AAP & $0.02297 \pm 0.0075$ & $0.01313 \pm 0.0032$ \\
\hline EP (Olsen-P) & $0.00177 \pm 0.0007$ & $0.00099 \pm 0.0005$ \\
\hline WSP & $0.00047 \pm 0.0001$ & $0.00043 \pm 0.0002$ \\
\hline RDP & $0.00002 \pm 0.0001$ & $0.00002 \pm 0.0001$ \\
\hline
\end{tabular}

Note: Results are expressed as the mean \pm standard deviations in $\mathrm{gP} \cdot \mathrm{d}^{-1}$ of dry matter (three replicates).

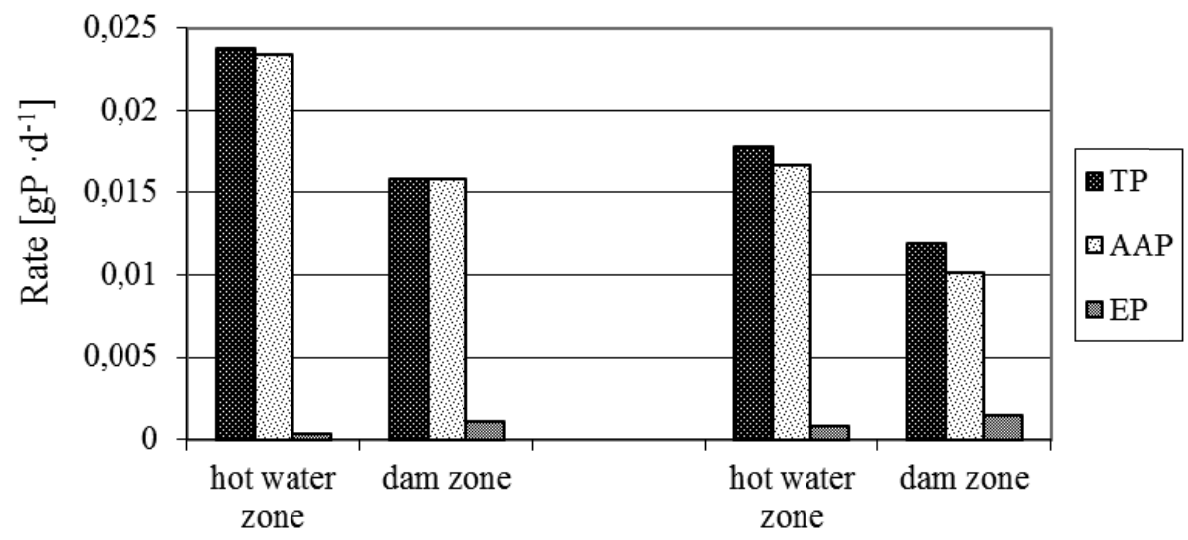

Growth rate

Decrease rate

Fig. 8. Speed of the increase and decrease in the phosphorus species concentrations in the heated water discharge and dam zones of Rybnik Reservoir

Table 2. Estimated phosphorus loads in the bottom sediments of selected dam reservoirs

\begin{tabular}{|c|c|c|c|c|c|c|c|c|}
\hline \multirow{2}{*}{ Reservoir } & Reservoir area & TP & AAP & EP (Olsen-P) & WSP & RDP & Mean \\
\cline { 2 - 9 } & ha & \multicolumn{5}{|c|}{ MgP } & MgTP/ha \\
\hline Rybnik & 450 & 1.300 & 1.235 & 46 & 39 & 6 & 3 \\
\hline Goczałkowice & 3.200 & 288 & 265 & 23 & 7 & 0.1 & 1 \\
\hline Pławniowice & 225 & 212 & 178 & 27 & 7 \\
\hline
\end{tabular}

Table 3. Pearson's correlation coefficients between the phosphorus species concentrations and redox potential in the bottom sediments $(n=19$, bold - significant correlations, $p<0.05)$

\begin{tabular}{|c|c|c|c|c|c|c|}
\hline Sampling points & \multirow{4}{*}{ Eh } & TP & AAP & EP (Olsen-P) & WSP & RDP \\
\hline Heated water discharge zone & & -0.2103 & -0.2406 & 0.4605 & 0.5585 & 0.6956 \\
\hline Pelagic zone & & 0.0413 & 0.0371 & 0.2541 & 0.3676 & 0.2254 \\
\hline Dam zone & & -0.0416 & -0.0716 & 0.5258 & 0.1954 & 0.4481 \\
\hline
\end{tabular}




\section{Phosphorus speciation forms in the upper and lower layers of sediments}

The correlation coefficients between the phosphorus species concentrations in the upper and lower sediment layers demonstrate similarities in the dynamics of changes occurring in both sediment layers throughout the year. The high values of the Pearson's correlation coefficients indicate a statistically significant positive correlation between the phosphorus species concentrations in the upper and lower layers of the Rybnik Reservoir bottom sediments (Table 4).

Therefore, the sediment samples used to investigate phosphorus speciation should be collected from two layers, i.e. the surface $(5 \mathrm{~cm}$ thickness) and lower $(5 \mathrm{~cm}$ thickness at the depth of $15-20 \mathrm{~cm})$ ones.

When the TP concentrations understood as a sum of specific speciation forms were compared with the TP concentrations obtained due to the complete sample mineralization, it turned out that a phosphorus form that could not be extracted with methods used for the bioavailable forms could occur in the bottom sediments of the limnic ecosystems. For this form, the proportionality coefficients changing along the longitudinal reservoir axis were calculated.

\section{Phosphorus speciation forms in Transect 1 and Transect 2}

Table 5 present the results of Independent T-Test for Two Samples of the phosphorus species concentrations in the bottom sediments (Transect 1 vs Transect 2). It has been shown that in the sediments collected from transect 1 and 2, there are statistically significant differences in the content of TP and phosphorus speciation forms (with the exception of EP). The results indicate the need to carry out research taking into account both upper and lower layer of sediments as well as the spatial location of sampling points (transect 1 and 2).

The spatial variability (i.e. the differences between phosphorus species concentrations between sampling points of Transects 1 and 2) was related with the oblong and transverse depth asymmetry, characteristic for lowland dam reservoirs. Consequently, it may be stated that determining the abundance of the limnic ecosystem with phosphorus compounds can only be approximate and done with the mean concentration values. To do that, it is necessary to take into account the ecosystem morphometric conditions and to select a proper number of the measurement points enabling the calculation.

\section{Conclusions}

1. Morphometric conditions of a dam reservoir - depth (from the viewpoint of the water mass stratification), oblong and transverse depth asymmetry, reservoir axis length - were related to the spatial and time variability of the phosphorus species concentrations in the bottom sediments.

2. The spatial thermal diversification of the water masses affected the intensity of the phosphorus transformations. In the heated water discharge zone, the transformation intensity was by approx. $35 \%$ higher than in the dam zone.

3. The assessment of the general abundance of the bottom sediments with phosphorus compounds and determination of the proportion between the element species can be based on the mean values and is approximate.

4. In Rybnik Reservoir, the efficiency of the phosphorus species extraction was in the following order: AAP > Olsen-P $>$ WSP $>$ RDP.

5. The sum of specific phosphorus species $(\mathrm{AAP}+\mathrm{Olsen}-\mathrm{P}$ $+\mathrm{WSP}+\mathrm{RDP}$ ) did not correspond to the total abundance of the bottom sediments with phosphorus. When the TP concentrations understood as a sum of specific speciation forms were compared with the TP concentrations obtained due to the complete sample mineralization, the proportionality coefficients changing along the large reservoir axis were obtained (1.33-1.48-1.52, respectively: S1-S2-S3). The finding indicates the occurrence of the residual fraction that could not be determined with the methods for the bioavailable fractions.

6. The aim of the limnological engineering is to define the threats and search for methods for the limnic ecosystem protection and reclamation. Therefore, various elements affecting phosphorus speciation in the bottom sediments (i.e. hydrological conditions, morphometric conditions of a lowland dam reservoir, including oblong and transverse depth asymmetry, changing quality of the supplying water) indicate the necessity to apply a research methodology that takes all these aspects into account.

Table 4. Pearson's correlation coefficients between the phosphorus species concentrations in the upper and lower layers of the Rybnik Reservoir bottom sediments $(n=19$, bold - significant correlations, $p<0.05)$

\begin{tabular}{|c|c|c|c|c|c|c|}
\hline Sampling points & & TP & AAP & EP (Olsen-P) & WSP & RDP \\
\cline { 1 - 5 } Heated water discharge zone & \multirow{4}{*}{ UL vs LL } & $\mathbf{0 . 9 5 8 6}$ & $\mathbf{0 . 9 5 6 9}$ & $\mathbf{0 . 8 8 8 8}$ & $\mathbf{0 . 7 4 2 5}$ & $\mathbf{0 . 8 4 2 7}$ \\
\cline { 1 - 5 } & & $\mathbf{0 . 8 7 5 0}$ & $\mathbf{0 . 8 6 8 8}$ & $\mathbf{0 . 8 9 9 7}$ & $\mathbf{0 . 9 0 0 6}$ & $\mathbf{0 . 8 3 6 2}$ \\
\cline { 1 - 5 } & & $\mathbf{0 . 9 4 4 1}$ & $\mathbf{0 . 9 4 3 7}$ & $\mathbf{0 . 9 1 5 7}$ & $\mathbf{0 . 7 3 2 8}$ & $\mathbf{0 . 8 6 8 1}$ \\
\hline
\end{tabular}

Table 5. The results of Independent T-Test for Two Samples of the phosphorus species concentrations in the bottom sediments $(\mathrm{n}(\mathrm{T} 1)=21 ; \mathrm{n}(\mathrm{T} 2)=36$, bold - significant correlations, $\mathrm{p}<0.05)$

\begin{tabular}{|c|c|c|c|c|c|c|}
\hline Transect & Layer & TP & AAP & EP (Olsen-P) & WSP & RDP \\
\hline \multirow{2}{*}{1 vs 2} & UL & $\mathbf{0 . 0 0 0 0 0 1}$ & $\mathbf{0 . 0 0 0 0 0 1}$ & 0.172868 & $\mathbf{0 . 0 0 0 0 0 7}$ & $\mathbf{0 . 0 0 0 8 1 3}$ \\
\cline { 2 - 7 } & LL & $\mathbf{0 . 0 0 0 0 0 1}$ & $\mathbf{0 . 0 0 0 0 0 1}$ & 0.128235 & $\mathbf{0 . 0 0 0 0 2 2}$ & $\mathbf{0 . 0 1 0 0 1 6}$ \\
\hline
\end{tabular}




\section{Acknowledgments}

This work was financially supported by the Ministry of Science and Higher Education under Grant "Variability of selected metals, metalloid, nitrogen and phosphorus speciation forms in water and sediments of the anthropogenic reservoir"; Task 1 - Phosphorus speciation forms in the Rybnik Reservoir (No. 1a-97/11/13).

\section{References}

Aimin, Z., Hongxiao, T. \& Dongsheng, W. (2005). Phosphorus adsorption on natural sediments: Modelling and effect of $\mathrm{pH}$ and sediment composition, Water Research, 38, pp. 1245-1254.

Aydin, I., Aydin, F., Saydut, A. \& Hamamci, C. (2009). A sequential extraction to determine the distribution of phosphorus in the seawater and marine surface sediment, Journal of Hazardous Materials, 168, pp. 664-669.

Bartoszek, L. (2007). Phosphorus release from the bottom sediment, Zeszyty Naukowe Politechniki Rzeszowskiej, 42, 240, pp. 5-15.

Bostrom, B., Persson, G. \& Broberg, B. (1998). Bioavailability of different phosphorus forms in freshwater systems, Hydrobiologia, 170, pp. 133-155.

Dunalska, J., Staehr, P.A., Jaworska, B. \& Górniak, D. (2014). Ecosystem metabolism in a lake restored by hypolimnetic withdrawal, Ecological Engineering, 73, pp. 616-623.

Frankowski, L., Bolałek, J. \& Szostek, A. (2002). Phosphorus in bottom sediments of Pomerania Bay (Southern Baltic-Poland), Estuarine, Coastal and Shelf Science, 54, pp. 1027-1038.

Gawrońska, H., Łopata, M. \& Jaworska, B. (2008). The effectiveness of the phosphorus inactivation methods in reducing the trophy of lakes of different morphometric and hydrological features, Limnological Review, 7, 1, pp. 27-34.

Gonsiorczyk, T., Casper, P. \& Koschel, R. (1998). Phosphorus-binding forms in the sediment of an oligotrophic and a eutrophic hardwater lake of the Baltic lake district (Germany), Water Science of Technology, 37, pp. 51-58.

Kaiserli, A., Voutsa, D. \& Samara, C. (2002). Phosphorus fractionation in lake sediments - Lakes Volvi and Koronia, N. Greece, Chemosphere, 46, pp. 1147-1155.

Kostecki, M. (2000). The suspended solids as an element of pollution of anthropogenic water ecosystem for example of Dzierżno Duże dam-reservoir (Silesia), Archives of Environmental Protection, 26, 4, pp.75-94. (in Polish)

Kostecki, M. (2002). Atmospheric precipitation as the element of pollutants budget on dam-reservoirs of the Kłodnica Water Junction, Archives of Environmental Protection, 28, 2, pp. 45-59. (in Polish)

Kostecki, M. \& Kozłowski, J. (2002). Nitrogen and phosphorus compounds in the water and bottom sediments of Gliwice Channel, Archives of Environmental Protection, 28, 2, pp. 71-87. (in Polish)

Kostecki, M. (2003). Allocation and transformation of selected pollutants in reservoirs of Kłodnica River Water-Junction system and The Canal Gliwice, Works \& Studies, Zabrze 2003. (in Polish)

Kostecki, M. (2004). Anthropopression impact on the formation of thermal structure on the Rybnik dam-reservoir, Archives of Environmental Protection, 4, pp. 41-53. (in Polish)

Kostecki, M. (2005a). The thermal conditions specificity of Rybnik reservoir as a result of discharge of heated water, Problemy Ekologii, 3, pp. 110-114. (in Polish)

Kostecki, M. (2005b). About the importance and necessity of protecting the anthropogenic water reservoirs of the Western Water Node of the Upper Silesia Industrial District, Problemy Ekologii, 9, 4, pp. 193-201. (in Polish)
Kostecki, M. \& Mazierski, J. (2008). Biodegradation of polycyclic aromatic hydrocarbons in bottom sediments in presence of calcium peroxide, Przemyst Chemiczny, 3, pp. 278-283. (in Polish)

Kostecki, M. \& Nocoń, W. (2010). The role of shallow, lowland dam reservoir in the river-lake-river system. Part II. Changes and equation of phosphorus in the Stupsko Dam-Reservoir, Inżynieria $i$ Ochrona Środowiska, 13, 4, pp. 245-257. (in Polish)

Kostecki, M. \& Suschka, J.(2013). The successful results of Pławniowice reservoir (Upper Silesia Region - South of Poland) restoration by hypolimnetic withdrawal, Archives of Environmental Protection, 39,1 , pp. 17-25.

Kostecki, M. (2014). Anthropogenic water reservoir Pławniowice restoration by hypolimnetic withdrawal method: limnological study, Works \& Studies, Zabrze 2014. (in Polish)

Koszelnik, P. (2007). Atmosphere deposition as a source of nitrogen and phosphorus loads into Rzeszow reservoir, SE Poland, Environmental Protection Engineering, 33, 2, pp. 157-164.

Kowalczewska-Madura, K., Jeszke, B., Furmanek, S. \& Gołdyn, R. (2005). Spatial and seasonal variation of phosphorus fraction in bottom sediments of the hypertrophic Swarzędzkie Lake (W Poland), Limnological Review, 5, pp. 123-128.

Kowalczewska-Madura, K., Gołdyn, R. \& Dera, M. (2015). Spatial and seasonal changes of phosphorus internal loading in two lakes with different trophy, Ecological Engineering , 74, pp. 187-195.

Nurnberg, G., Hartley, R. \& Davis, E. (1987). Hypolimnetic withdrawal in two north American lakes with anoxic phosphorus release from the sediment, Water Research, 21, 8, pp. 923-928.

Olsen, S.R., Cole, C.V., Watanabe, F.S. \& Dean, L.A. (1954) Estimation of available phosphorus in soils by extraction with sodium bicarbonate, Circular/ United States Department of Agriculture, Washington 1954.

Pettersson, K., Bostrom, B. \& Jacobsen, O.S. (1988). Phosphorus in sediments - speciation and analysis, Hydrobiologia, 170, pp. 91-101.

Sapek, A. \& Sapek, B. (2011). Phosphorus in atmospheric deposition, Ochrona Środowiska i Zasobów Naturalnych, 50, pp. 122-133. (in Polish)

Sharpley, A.N., Troeger, W.W. \& Smith, S.J. (1991). The measurement of bioavailable phosphorus in agricultural runoff, Journal Environmental Quality, 20, pp. 235-238.

Siuda, W. (2001). Enzymatic regeneration of orthophosphate in lake water, Postępy Mikrobiologii, 40, 2, pp. 187-217. (in Polish)

Smal, H., Ligęza, S., Baran, S., Wójcikowska-Kapusta, A. \& Obroślak, R. (2013). Nitrogen and phosphorus in bottom sediments of two small dam reservoirs, Polish Journal of Environmental Studies, 22, 5, pp. 1479-1489.

Smal, H., Ligęza, S,. Baran, S. \& Wójcikowska-Kapusta, A. (2015). Quantity and quality of organic carbon in bottom sediments of two upland dam reservoirs in Poland, Environmental Protection Engineering, 41, pp. 95-110.

Sondergaard, M. (1988). Seasonal variations in the loosely sorbed phosphorus fraction of the sediment of a shallow and hypereutrophic lake, Environmental Geology and Water Science, 11, 1, pp. 115-121.

Stawecki, K., Zdanowski, B. \& Dunalska, J. (2004). Seasonal changes in phosphorus concentration in the heat waters of Lake Mikorzyńskie, Limnological Review, 4, pp. 249-254.

Wang, L. \& Liang, T. (2015). Distribution characteristics of phosphorus in the sediments and overlying water of Poyang Lake, PLoS One, 10,5:e0125859.doi: 10.1371/journal.pone.0125859.

Wiliams, J.D.H., Shear, H. \& Thomas, R.L. (1980). Availability to Scenedesmus quadricauda of different forms of phosphorus in sedimentary materials from the Great Lakes, Limnology and Oceanography, 25,1, pp. 1-11. 
Zhou, Q. \& Zhu, Y. (1999). Simulated studies on degradation of organic matter and release of $\mathrm{CO}_{2}$ and $\mathrm{CH}_{4}$ in sediment from West Lake under various oxygen-supply conditions, Acta Scientiae Circumstantiae, 19, pp. 11-15.

Zhou, Q., Gibson, E. \& Foy, R.H. (2000). Long-term changes of nitrogen and phosphorus loadings to a large lake in North-West Ireland, Water Research, 34, pp. 922-926.
Zhou, Q., Gibson, Ch. E. \& Yinmei, Z. (2001). Evaluation of phosphorus bioavailability in sediments of three contrasting lakes in China and the UK, Chemosphere, 42, pp. 221-225.

PN-C-04541:1978 - Water and Sewage - Determination of the dry residue, residue on ignition, loss on ignition and solute substances, mineral solute substances and volatile solute substances. (in Polish)

\title{
Czasowa i przestrzenna zmienność stężeń specjacyjnych form fosforu w warunkach termicznego skażenia zbiornika - studium przypadku: Zbiornik Rybnicki
}

\begin{abstract}
Streszczenie: Celem pracy było zbadanie relacji czasowej i przestrzennej pomiędzy poszczególnymi formami specjacyjnymi fosforu, oraz ogólnej zasobności w fosfor, w osadach dennych antropogenicznego, hipertroficznego ekosystemu limnicznego Zbiornika Rybnickiego, funkcjonującego w warunkach skażenia termicznego. Stwierdzono, że dominującą formą specjacyjną fosforu w obu warstwach osadów dennych była frakcja algal available phosphorus $(83 \%)$, z kolei najmniejszy udział stanowiła frakcja redaily desorber phosphorus $(0.1 \%)$. Do oznaczenia form biodostępnych fosforu zastosowano procedurę ekstrakcji chemicznej. Stężenie form specjacyjnych fosforu było zależne od stężenia materii organicznej. Różnice pomiędzy zawartością specjacyjnych form fosforu w górnej $(5 \mathrm{~cm})$ i dolnej $(15-20 \mathrm{~cm})$ warstwie rdzenia osadów były niewielkie. Czynna biologicznie warstwa osadów sięgała od ich powierzchni do co najmniej $20 \mathrm{~cm}$ rdzenia osadów. Zaobserwowano, że rozkład stężeń poszczególnych form fosforu w skali roku jak i na poszczególnych stanowiskach, wynikał ze zmienności stanowiskowej oraz z intensywności przemian zachodzących $\mathrm{w}$ zbiorniku. W opracowaniu przedstawiono także stałe szybkości wzrostu oraz spadku stężenia specjacyjnych form fosforu w osadach dennych. Stwierdzono, że szybkość przemian fosforu w osadach dennych była zależna od warunków termicznych środowiska. Wykazano, że w strefie zrzutu wód podgrzanych (temp. wody $17-35^{\circ} \mathrm{C}$ ) szybkość wzrostu stężenia wskaźników wybranych form fosforu jest wyższa niż w strefie zapory $\left(5-25^{\circ} \mathrm{C}\right)$. Ponadto stwierdzono, że zasobność osadów dennych w specjacyjne formy fosforu pozostaje w związku z podłużną i poprzeczną asymetrią misy zbiornika.
\end{abstract}

